\title{
Chapter 2 \\ The Promise of Non-arm's Length \\ Practices: Is the Destination-Based Cash \\ Flow Tax or Unitary Taxation the Panacea \\ of Which Developing Countries Are \\ in Search?
}

\author{
Afton Titus
}

\subsection{Introduction}

Africa is at an unprecedented precipice of continental unity with the signing of the African Continental Free Trade Area Agreement (AfCFTA). At a time when some Western countries are implementing measures to move away from other countries, African countries are working toward greater unity. The signing of the AfCFTA heralds the eventual formation of a continent-wide single market. While the extent of integration under the AfCFTA currently involves the removal of tariffs and the cooperation on intellectual property, investment, and competition policies, the time seems opportune to speculate as to the direction of a continental-wide, unified approach to transfer pricing. It is estimated that Africa loses approximately US\$50 million annually through illicit financial flows (United Nations Economic Commission for Africa (UNECA) and the African Union Commission (AUC) 2015), of which transfer pricing is cited as one of the main contributors to such losses (UNECA and AUC 2014; Readhead 2016).

Transfer pricing is understood as determining the "remuneration for the transfer of goods, intangibles and the provision of services among related enterprises" (Hamaekers 2001). As more than $70 \%$ of all global trade occurs between related parties, transfer pricing concerns are of primary relevance to multinational enterprises and revenue authorities alike (ibid.).

The reason for determining transfer prices arises from the fear that multinational enterprises with several branches in foreign countries may shift profits into low tax jurisdictions (ibid). In such low tax jurisdiction, the further fear is that such profits

\footnotetext{
A. Titus $(\bowtie)$

University of Cape Town, Cape Town, South Africa

e-mail: afton.titus@uct.ac.za 
either may not be subject to tax at all or may be subject to only a nominal tax. It would seem then that the fears that transfer pricing is meant to allay are not so much that the country of residence may not get to tax the profits but rather that the source country will not levy the necessary taxes.

Over time, the arm's length principle became the standard agreed by the Organisation of Economic Co-operation and Development (OECD) members in determining transfer prices for the purposes of corporate income taxation (Russo 2005). As the OECD grew in influence internationally, this standard became the international standard. The arm's length standard deems dealings between associated enterprises to be controlled transactions which have to be adjusted to reflect the uncontrolled transactions which would have been concluded between independent parties in comparable circumstances to the associated enterprises (Rogers-Glabush 2015). The arm's length principle was initially designed to apply to intra-company dealings between the head office and branch of a company (Russo 2005). Its scope was later broadened to also apply to the transactions concluded between separate entities, such as the subsidiary and the parent company (ibid.).

It has been noted that the essence of the arm's length principle is to ensure that related enterprises deal with each other as they would with independent parties (Hamaekers 1997). The overarching rationale for this is to guarantee the equal tax treatment of multinational enterprises and independent companies and, in so doing, to avoid the distortive effects of competition (OECD 2017).

Overall then, transfer pricing was designed to ensure that the profits of multinational enterprises are subject to corporate income tax somewhere and, in so doing, minimize the competitive edge multinationals enjoy so as to make the playing field level for independent companies. In seeking to achieve this end through the arm's length principle, the drawbacks and challenges arising from the implementation of this principle have become apparent, especially as it applies in the developing country context. This has led to a call for developing countries to question whether the arm's length principle is suited for their particular context (Waris 2017).

This chapter responds to that call by undertaking such an evaluation under the auspices of the AfCFTA and its potential to create unity across Africa. While the time for fiscal unity in Africa may not yet be upon us, it is nonetheless useful to begin thinking about the direction Africa may one day possibly take with respect to transfer pricing.

This chapter therefore evaluates whether non-arm's length standards, such as unitary taxation and the destination-based cash flow tax (DBCFT), may be suitable alternatives to the arm's length standard for African developing countries when calculating the taxable profits of multinational companies. In considering this context, the author has selected two African developing countries-Kenya and South Africa-by which to provide this context.

As two of Africa's biggest economies and equally ranked in terms of the attractiveness to investors according to Ernst and Young's 2017 Africa Attractiveness Index, the corporate income tax policies adopted by these two African countries are likely to attract the attention of investors and other African countries alike. Moreover, Kenya and South Africa are two African countries who have had the 
longest-standing transfer pricing departments within their respective revenue authorities (UNECA and AUC 2015; Waris 2017). This means that these two countries are best placed to make an informed decision regarding a possible move away from the arm's length standard. As such, Kenya and South Africa serve as useful contexts.

In doing so, this chapter is presented in the following order: First, the arm's length standard is analyzed together with its advantages and disadvantages. This is followed by similar analysis of the unitary taxation and DBCFT models before the possible application of these non-arm's length models to the developing country context of Kenya and South Africa is then discussed. Thereafter, this chapter concludes.

\subsection{An Evaluation of the Varying Models}

\subsubsection{The Arm's Length Principle}

The arm's length principle first made its appearance in the "Draft Convention for the Allocation of Business Profits between States for the purposes of Taxation" prepared in 1933 by the Fiscal Affairs Committee of the League of Nations (see Appendix to Carroll 1934). Article 3 dealt with determining the profits of permanent establishments as follows:

If an enterprise with its fiscal domicile in one contracting State has permanent establishments in other contracting States, there shall be attributed to each permanent establishment the net business income which it might be expected to derive if it were an independent enterprise engaged in the same or similar activities under the same or similar conditions. Such net income will, in principle, be determined on the basis of the separate accounts pertaining to such establishment. Subject to the provisions of this Convention, such income shall be taxed in accordance with the legislation and international agreements of the State in which such establishment is situated. The fiscal authorities of the contracting States shall, when necessary, in execution of the preceding paragraph, rectify the accounts produced, notably to correct errors or omissions or to re-establish the prices or remunerations entered in the books at the value which would prevail between independent persons dealing at arm's length. If an establishment does not produce an accounting showing its own operations, or if the accounting produced does not correspond to the normal usages of the trade in the country where the establishment is situated, or if the rectifications provided for in the preceding paragraph cannot be effected, or if the taxpayer agrees, the fiscal authorities may determine empirically the business income by applying a percentage to the turnover of that establishment. This percentage is fixed in accordance with the nature of the transactions in which the establishment is engaged and by comparison with the results obtained by similar enterprises operating in the country. If the methods of determination described in the preceding paragraphs are found to be inapplicable, the net business income of the permanent establishment may be determined by a computation based on the total income derived by the enterprise from the activities in which such establishment has participated. This determination is made by applying to the total income coefficients based on a comparison of gross receipts, assets, number of hours worked, or other appropriate factors, provided such factors be so selected as to ensure results approaching as closely as possible to those which would be reflected by a separate accounting. 
From this extract it can determined that the profits of the permanent establishment were to be established through the following methods:

1. Adjusting the accounting books of the permanent establishment in order to deem arm's length transactions.

2. Applying a fixed percentage to the turnover of the permanent establishment, such percentage is to be determined to produce the results that would have been produced had a comparable resident company undertaken transactions of a similar nature.

3. Creating a simulation of separate accounting through determining the total income of the permanent establishment. This is done by creating coefficients from comparisons of the gross receipts, assets, number of hours worked, and other suitable factors of other businesses.

As Langbein (1986) has argued, these are essentially accounting or bookkeeping methods to determine an accounting profit that governments want to subject to tax. Moreover, the arm's length principle relies on the separating accounting approach to determining such profits (Sadiq 2001). Despite the fact that the arm's length principle rests on a non-legal methodology, the proponents of this standard argue that the following advantages may be gained from applying the principle as a legal standard:

1. It is a norm of international tax that is widely accepted in the international community (ibid.; Green 1993).

2. It creates an equality in the tax treatment of related and unrelated companies (Sadiq 2001; Green 1993).

3. It most accurately determines the "true" source of income (McLure and Weiner 2000).

Commentators, however, doubt the veracity of the above. Hellerstein (2005) argues that it is not at all clear that the arm's length principle is an internationally accepted norm, a point made by Langbein (1986) decades earlier. Moreover, De Graaf et al. (2014) question the feasibility of an "equal" treatment of related and unrelated companies when in doing so the arm's length standard ignores the synergies arising from corporate integration, a state of affairs which is in fact an economic reality. Economic reality is further ignored when the arm's length principle takes into account interim profits as they arise in the group context before the profits are actually realized and when losses within the group cannot be balanced against the profits of other group members (Hertzig et al. 2010). Finally, Hellerstein (2005) questions whether determining the "true" source of income is a worthwhile endeavor. Instead, it is argued that income should be allocated to countries which have a claim to it based on an equitable distribution of such income (ibid.; McIntyre 2003).

Notwithstanding the purported advantages of the arm's length principle, the numerous difficulties encountered in applying the arm's length principle to determine transfer prices are well documented (Avi-Yonah 2007; Avi-Yonah and Benshalom 2011; Sadiq 2004; Turina 2018). These difficulties have made the implementation of the principle "extraordinarily complex" (Hellerstein 2005). 
Moreover, it has been noted that the arm's length principle does not adequately address abuses while at the same time allowing revenue authorities to maximize their tax collections through taking advantage of the uncertainties in implementing the arm's length principle (Avi-Yonah and Musselli 2019).

In the light of these challenges, Brooks (2009) suggests that the time may be opportune for developing countries to devise an alternative means by which to equitably allocate income between countries.

\subsubsection{Unitary Taxation}

Unitary taxation works from the premise that the financial performance of companies whose businesses are integrated, such as in the case of a group of companies, should be combined in order to capture the synergies arising from such integration (Hellerstein 2005). While formulary apportionment complements unitary taxation, unitary taxation may be implemented without it (ibid.; Weiner 1999). Formulary apportionment envisages that the profits of multinational companies should be allocated across the countries in which such companies operate on the basis of a formula which accounts for where the income-producing activities are conducted (ibid.). While the choice of factors which are to make up this formula is ultimately a political choice (Hertzig et al. 2010), the prevailing formula is one based on an equal weighting of the three factors of production (labor, capital, and assets) and sales as a representation of demand (Kobetsky 2008).

Unitary taxation differs from the arm's length principle in that it is not applied to every transaction in order to produce a profit or loss on that transaction which then cumulatively becomes the taxable profit (Hertzig et al. 2010). Instead, unitary taxation produces a single, consolidated profit for the entire integrated business. In doing so, one of the advantages of a unitary tax system is that it eliminates the need for transfer pricing as the transactions occurring between the components of the integrated business are ignored (ibid.; Kobetsky 2008). Proponents of unitary taxation argue that a further advantage of the system is that it more accurately reflects economic reality (Bird 1986; Sadiq 2001; Weiner 1999). Economic reality is reflected by the fact that no interim profits within the group of companies are generated; the synergies arising from an integrated business are accounted for; and losses are set off against profits of companies belonging to the same group (Hertzig et al. 2010). Furthermore, unitary taxation would allow for greater certainty. This is especially as every step of applying the unitary taxation system would have to be legislated (Langbein 1986). These steps would encompass the rules for consolidation and the factors in terms of which the consolidated profits are to be allocated across countries. Langbein (1986) notes that such legislative measures would ensure that very little room is left for manipulation and would necessitate effective taxpayer information disclosure.

It has also been argued that a unitary taxation system would result in greater efficiency and fairness (Sadiq 2001). Efficiencies are created through a tax system 
which recognizes the efficiencies achieved by the integration of businesses (ibid.) and through resource saving as taxpayers and revenue authorities alike are freed from the complexities of transfer pricing determinations and the resultant disputes (Kobetsky 2008). Fairness is fostered through a tax system which uses the actual financial performance of the integrated business and not that of comparables which effectively attributes the business acumen and decisions of others onto the taxpayer (Kauder 1993). Formulary apportionment also creates fairness by allowing the tax system to follow the economic choices made by the taxpayer itself as profits are allocated to countries based on the economic decisions of the taxpayer (Sadiq 2001). Finally, it is argued that a benefit of unitary taxation is that it reduces the incidence of tax evasion and avoidance due to the extent of the reorganization that would be required from integrated businesses when seeking to evade or avoid taxes (ibid.).

Unitary taxation is not without its disadvantages. First, it has been argued that difficulties may be encountered in defining the level at which businesses will be considered to be integrated (Hertzig et al. 2010). If the threshold is set too low, it may overstate the synergies arising from integration (ibid.). If the threshold is too high, it may not properly reflect the economic realities of an integrated business (ibid.). Secondly, the prospect of having a consolidated profit subject to tax presents different tax planning opportunities (ibid.). The third criticism relates to formulary apportionment in that the arbitrariness of the factor selection may lead to inappropriate results in so far as income may be allocated to low-tax countries despite the absence of significant income-generating activities located there (ibid.).

Moreover, Fargas Mas (2018) argues that while the concept of a unitary tax system is attractive, the difficulty lies in determining who is to be responsible for drawing up the rules for such consolidation. It was suggested that this could be done by relying on the International Financial Reporting Standards (IFRS) (ibid.). However, Fargas Mas (2018) points out the criticisms of such an approach in that this would allow the accounting bodies who draw up the IFRS to effectively decide the taxable base and become legislators.

Despite its flaws, many have strongly advocated for the global adoption of unitary taxation coupled with formulary apportionment, arguing that such a system is more equipped to deal with the challenges of taxing an integrated business (Bird 1986; Sadiq 2001; Kobetsky 2008).

\subsubsection{Feasibility in an African Developing Country Context}

Both Kenya and South Africa currently adopt the arm's length principle as a means of allocating profits arising from the transactions concluded between components of an integrated business (Kenya: Income Tax Act, Chapter 470, section 18(3) and South Africa: Income Tax Act, No. 58 of 1962, section 31). In this regard, both countries closely follow the OECD Guidelines (2017). It would therefore constitute a major shift for both countries to implement unitary taxation along with formulary apportionment. 
Having said that, recent studies have indicated that perhaps Kenya and South Africa should seriously consider making such a shift (Waris 2017; Wier and Reynolds 2018). At the moment, transfer pricing cases take up an extraordinary amount of resources for both the Kenya Revenue Authority (KRA) and the South African Revenue Service (SARS). Both the KRA and SARS have dedicated transfer pricing units with the KRA having grown their staff complement to 34 members recently (Okuth 2018), while SARS has had long-standing plans to do the same (PWC 2012). Despite dedicating staff to transfer pricing issues, transfer pricing cases take an extraordinarily long time to be finalized in both countries. A transfer pricing case takes on average between $1 \frac{1}{2}$ and 4 years to be completed in South Africa (OECD 2019). In Kenya, the average transfer pricing case takes approximately 4-5 years to be completed (Waris 2017). Moreover, in order to deal effectively with transfer pricing issues, staff have to be exceptionally well trained. Kenya was one of the first recipients of transfer pricing training by the OECD in 2009 (Waris 2017), and the KRA now boasts members of its transfer pricing units who are experts in analyzing the various disclosures to be made in transfer pricing documentation (KPMG 2015). Thus, the KRA has experts in functional analysis, asset analysis, risk analysis, and economic analysis, for instance (KPMG 2015).

Notwithstanding these measures, Kenya and South Africa are still losing substantial revenues as a result of transfer pricing. While a 2018 report indicated that Kenya lost US\$907 million in 2013 (Global Financial Integrity 2018), this number may be much higher today given the number of multinational companies operating in Kenya whose annual turnover exceeds 750 million euros (Initiative for Global Development and Dalberg Global Development Advisors 2011; Waris 2017). Similarly, South Africa loses approximately US\$475 million annually as a result of transfer pricing (Donnelly 2019; Wier and Reynolds 2018).

These losses may be attributed to the problems experienced by Kenya and South Africa in implementing the arm's length standard in their respective countries. The arm's length standard is particularly problematic in Kenya and South Africa because both these countries deal with many large multinational companies that effectively operate as monopolies in their industries (Waris 2017; Wier and Reynolds 2018). This issue is particularly significant in South Africa where a report recently concluded that $80 \%$ of the income earned by foreign-owned firms in South Africa were earned by only $10 \%$ of the largest of those firms (Wier and Reynolds 2018).

Furthermore, implementation of the arm's length standard requires the availability of a large database of comparables. This is difficult to construct in Kenya because the digitization of company records is still incomplete (Waris 2017). Similarly in South Africa, the availability of comparable data is hampered by the fact that it is only public companies who are required to make their financial records available to the public (Companies Regulations 2011; Deloitte 2015).

If Kenya and South Africa were to implement unitary taxation, it would immediately free up the government resources and time as discussed above. This would result in the administrative capacity to retrain staff in a new system. 
Kenya and South Africa, however, would have to make the decision at which level to define when a business has a sufficient degree of integration to bring about unitary taxation. While this would be a difficult decision, the author is of the view that South Africa has already laid the groundwork for this sort of discussion when deciding at which stage parties would be affiliated or related to each other in applying the arm's length principle under its existing laws. In this regard, it is suggested that perhaps this discussion should begin with whether South Africa's definition of a "group of companies" in Section 1 of its Income Tax Act is adequate in capturing what is meant by an "integrated business."

A unitary taxation system would allow the taxation of multinationals' profits to be more closely aligned with economic reality while also providing the concomitant benefits of a fair and efficient system.

In the light of the above, it would seem that perhaps it would not be too onerous for Kenya and South Africa to consider implementing a unitary taxation system. In a similar vein, the adoption of a formulary apportionment system may also be beneficial to these countries.

Kenya is a unique position in that it is home to both foreign and resident multinationals (Kelley 2011). Moreover, Kenya and South Africa are preferred destinations for multinationals (EY Attractiveness Africa 2019). As such, Kenya and South Africa would be more likely than other African countries to have the factors of production housed within their borders. It may therefore be beneficial for Kenya and South Africa to adopt the equally weighted factors of assets, capital, labor, and sales.

Aside from the difficult decision of deciding on which factors are to make up the formula, once this decision is made, it is noted that a legislative approach to how profits of multinationals are to be allocated across countries may benefit Kenya and South Africa in that it would allow greater certainty for both taxpayers and revenue authorities while also allowing for less room for discretion within may result in fewer disputes.

Moreover, if Kenya and South Africa were to reach consensus on which factors they would use in their formulas, as two of the biggest economies in Africa, it may pave the way for other countries in Africa to adopt similar formulas - and perhaps this process may be facilitated by the AfCFTA. Historically, such natural cooperation has occurred before.

It has been noted that in the United States when Iowa unilaterally adopted a salesbased apportionment with respect to corporate income tax, this triggered a "spontaneous coordination" as other states followed suit while pursuing their own best interest (De Wilde 2016). De Wilde argues that it is not inconceivable for a similar "spontaneous cooperation" to occur on a global level (ibid.). Similarly, the author argues that the AfCFTA could allow for a similar "spontaneous cooperation" to happen in Africa at the impetus of two of the biggest economies in Africa, Kenya and South Africa-if such a move were in the best interest of the individual countries. It is submitted that a move to unitary taxation combined with formulary apportionment may well be in the best interest of African countries. 
In this way, the necessary political consensus among African countries may be reached on such a scale that it may minimize the likelihood of double or non-taxation arising from differences in approaches to formulary apportionment between African countries.

In respect of the rest of the world, however, it is noted that Kenya and South Africa have concluded a number of double taxation agreements. Their obligations under these treaties would have to be factored in when making the decision to move away from the arm's length standard. The Independent Commission for the Reform of International Corporate Taxation (ICRICT) suggests that countries considering such a shift should implement unitary taxation and formulary apportionment as a minimum alternative tax to the arm's length standard (ICRICT 2018). In terms of this approach, the multinational company's tax liability would be calculated both in terms of the arm's length standard, as required by most double taxation agreements, and in terms of unitary taxation with formulary apportionment (ibid.). Only in the event that liability under the arm's length standard is less than the result under unitary taxation with formulary apportionment would the amount as determined under the non-arm's length standard apply (ibid.).

While this methodology would be time-consuming, it may serve as a transitional measure for African countries wishing to adopt unitary taxation with formulary apportionment as a standard until (and if) this becomes a uniform position across African countries.

In considering the above, the author is of the view that a unitary taxation system coupled with formulary apportionment may be a viable alternative to the arm's length principle for Kenya and South Africa on a principled basis. Significant administrative challenges would have to be addressed by both countries in implementing such a change, a discussion of which would be beyond the scope of this chapter. However, these challenges would not diminish the fact that unitary taxation and formulary apportionment would hold great promise if it were implemented in Kenya and South Africa.

\subsubsection{Destination-Based Cash Flow Tax}

The DBCFT was first proposed by Bond and Devereux in 2002 (Bond and Devereux 2002) and has more recently been the subject of discussion (Auerbach 2017; Auerbach et al. 2010, 2017a, b; Avi-Yonah and Clausing 2017). The DBCFT basically envisages that tax on corporate income or profits should be levied at "destination," that is, the country in which the final sales to customers are made should be allowed to levy the tax (Cui 2017). This prospect produces an alternative to "residence" and "source" paradigms (ibid.).

It has been noted that there are two versions of the DBCFT currently in the literature (ibid.). The first is the taxation of corporate income through a sales-only formulary apportionment (Auerbach et al. 2010; De Wilde 2018). The second is a destination-based value added tax (VAT) with deductions for labor costs and 
refundable losses (Auerbach and Devereux 2013). Each of these shall be analyzed in turn.

\subsubsection{Sales-Only Formulary Apportionment}

Some of the advantages of shifting to this method of taxing corporate profits lies in its movement away from the residence/source paradigm with all its known problems (Cui 2017); its potential to remove known profit-shifting opportunities should the DBCFT be adopted globally (Hebous et al. 2019); and its potential to make the tax rate irrelevant to firms deciding on the location of their operations (ibid.).

The sales-only formulary apportionment method of taxing corporate income is a new element to the international tax melting pot. This method envisages that the corporate income should be divided among the countries where the goods or services are sold (Cui 2017). This method was initially proposed by Auerbach, Devereaux, and Simpson (2010) before being discussed by De Wilde (2018) in the context of the EU's CCCTB proposal. De Wilde (2018) suggests that the EU should abandon the CCCTB proposal altogether in favor of adopting a unitary tax system based on salesonly formulary apportionment. De Wilde (2018) argues that this system with its worldwide tax consolidation of multinational companies would allow economic profits to be taxed while moving away from the flawed and vulnerable residence and source paradigms. De Wilde (2018) further argues that a sales-only formulary apportionment would allow EU Member States to once again obtain control of the tax policy function of corporate income tax as the control of the location of corporate profits would be taken away from companies.

This method, however, is not without its criticisms. Fargas Mas (2018) argues that the reliance on a sales-only formulary apportionment method would effectively exclude most developing countries from participating in the allocation of taxing rights. This is because most sales typically take place in a developed country (ibid.).

Further criticism of the sales-only formulary method lies in the fact that it would be ineffectual to apply in the case of intermediary or business-to-business sales (Cui 2017). Cui (2017) argues that if the destination-based, sales-only factor should be applied in intermediary sales, this would allow the parties to the sale agreement to decide on the location of the sale (and where tax is levied) in the same way as is the case now with respect to the manipulation of the production factors, assuming that there is collusion between the purchaser and seller. It has been noted that sales to actual final customers are evident in only a very small percentage of cases, and therefore the potential for manipulation of the sales-only formulary method is great (ibid.).

A further complication of implementing this method is that it is not customary for sellers to gather information on the purchasers (ibid.). The sales-only formulary apportionment method would therefore require the seller to undertake informationgathering activities, a new cost which would have to be absorbed by sellers (ibid.). Similar information-gathering complications would play out on an international level. Cui (2017) argues that the sales-only formulary apportionment method 
would require multilateral cooperation from all the countries involved-residence, source, and destination. Costs still need to be allocated to the sales which means that the country of destination would require the country of production to provide such information (ibid.). Cui (2017) therefore questions whether a sales-only formulary apportionment method is really different from the current system.

With respect to information-gathering, the author notes that perhaps it would be worthwhile to consider the mechanisms employed under the VAT system to keep track of the destination of the sales and to acquire the necessary customer information.

\subsubsection{Destination-Based VAT Adjusted for Wages}

The second form of the DBCFT is a destination-based VAT with deductions for labor costs and refundable losses. In terms of this destination-based VAT method, no interest or depreciation would be deductible, while investment expenses would be deductible (Auerbach 2017). In this way, this method seeks to exclude the normal return on investment and only tax economic rents (ibid.). Moreover, a border adjustment is to be made such that income arising from exports is exempted while no deduction is allowed for imported inputs (ibid.).

Advantages of this method lie in the more balanced tax treatment of the returns of debt and equity capital; the simplification of the tax system in removing the need to calculate income; and the fairness involved in not taxing the normal return on investments (ibid.).

Hebous et al. (2019) speculate that this method would benefit developing countries. They argue that revenues in developing countries should increase because developing countries are generally capital importers with big trade deficits. Moreover, they opine that developing countries would benefit from replacing tax incentives with a cash flow tax in that such a decision would likely broaden the tax base in developing countries and in so doing bring in more revenue. However, Hebous et al. (2019) do acknowledge that developing countries who rely on location-specific rents and revenue from natural resources would probably lose out upon implementing this method. Moreover, they note that this method would be more volatile than corporate income tax as a consequence of investments varying more than depreciation allowances (ibid.). Such volatility would be exacerbated in developing countries with the immediate tax refund function of the destination-based VAT system (ibid.).

Immediate tax refunds would be a reality, Auerbach (2017) notes because the adoption of this method would see the increase of net operating losses of taxpayers-especially for taxpayers with large amounts of export sales. Auerbach et al. (2017b), however, suggest that perhaps the loss should be allowed to be offset against other taxes such as payroll taxes. Should this be implemented instead of an immediate release of a refund, perhaps the volatility of this method could be reduced. A further drawback of this method is the difficulties arising from taxing financial institutions (ibid.). In this respect, Auerbach (2010) suggests that the current system of allowing for a deduction of interest and the taxation of interest received should be 
retained while now also allowing for the taxation of amounts borrowed and the deduction of amounts lent. Moreover, concerns have been raised that this method would not be compatible with the World Trade Organization agreements (ibid.).

Grinberg (2017), however, argues that adjustments may be made to this method to make it compatible with the World Trade Organization agreements. According to Grinberg (2017), first the tax base should be clearly defined as being a tax on domestic consumption such that the normative parameters of the tax are evident. Next, all businesses operating within the domestic market must be registered as DBCFT taxpayers, while non-resident businesses may choose not to be so registered (ibid.). DBCFT taxpayers would be allowed to deduct all wages paid to resident taxpayers, while wages paid to non-resident aliens would not be deductible (ibid.,). Moreover, DBCFT taxpayers would be entitled to deduct non-financial payments made to other DBCFT taxpayers (ibid.). Should a business choose not to register as a DBCFT taxpayer, other DBCFT taxpayers would not be allowed to deduct the payments made to that non-registered business (ibid.). Grinberg (2017) argues that the World Trade Organization case law provides that World Trade Organizationcompliant tax systems are to treat imported products and domestic products similarly unless the importer does not adhere to defensible administrative rules.

A major concern of this method, however, is that it introduces nothing new to the international tax arena (Cui 2017). Instead, this method may only serve to create significant trade distortions while failing to tax what is intended-corporate profits (ibid.; Shaviro 2018). This is because this method would only change the amount of the corporate's inputs and outputs while it would leave the profits that ultimately accrue to the shareholders unaffected (Cui 2017). In the light of this, Shaviro (2018) questions whether a country would effectively have two VAT systems if it were to adopt this form of the DBCFT when it already has a VAT system. Shaviro (2018) further questions whether the adoption of this form of DBCFT in conjunction with a VAT system would have any utility.

A further concern is that this DBCFT method only serves to allocate revenue to where shareholders reside and not where customers reside (ibid.). This is because the labor compensation is excluded which results in the taxation of only consumption financed by domestic profits-the domestic economic rent on capital (ibid.). A pure tax on consumption would tax all domestic consumption irrespective of whether it is generated by labor or economic rent and regardless of where such elements are generated (ibid.). This method would not do this (ibid.). Finally, Cui (2017) opines that the immediate loss refund feature is not administratively feasible for most countries.

From a substantive point of view, commentators agree that the DBCFT proposals do not introduce anything new to international tax. As such, it is unlikely to be a serious contender to replacing the arm's length principle. 


\subsubsection{Feasibility in an African Developing Country Context}

Both Kenya and South Africa currently implement a classical corporate income tax system. A switch to a DBCFT system would therefore constitute a major overhaul. In considering whether such an overhaul would be worthwhile, it is sobering to consider the transitional costs that such a change would incur. It was estimated that if the United States were to implement a DBCFT, it would result in a US $\$ 5$ trillion loss in the value of foreign assets held by US residents, while non-residents would realize a US\$8 trillion gain on the value of US-held assets as the US\$ would appreciate against foreign currencies (Graetz 2017). Such transitional costs would be prohibitive in an African developing country context.

Notwithstanding the transitional costs, the sales-only formulary apportionment method may be attractive, but only in so far as the sales actually were to take place within Kenya or South Africa. Should the sales take place elsewhere, Kenya and South Africa would stand to lose its taxing rights - rights which it otherwise may have had if the production factors of the multinational company were actually housed in their countries. More importantly, the complications which would arise from intermediate sales and the administrative difficulties involved in keeping track of where the final consumers are located would be an additional administrative burden on the respective revenue authorities. It is therefore doubtful whether it would be worth Kenya and South Africa making the normative and administrative leap to adopt a sales-only formulary apportionment method of taxing corporate income.

Similarly, adopting a destination-based VAT method with a deduction for labor and allowing for immediate loss refunds would probably not be feasible for Kenya and South Africa. Administratively, allowing for the immediate refund of losses would create too great a risk for fraud, especially when both countries are already plagued with VAT-related fraud. Moreover, given the questionable normative difference between this method and VAT regarding who and what is ultimately subject to tax, and given that both Kenya and South Africa already have VAT systems in place, the destination-based VAT method would not hold much promise for Kenya and South Africa.

The author is of the view that the only real advantage these two African developing countries may possibly gain from a switch to a DBCFT system-in whatever form-would be to capitalize on the "novelty" aspect of such a change. The two countries could possibly benefit from mobile capital attracted by the shift in method of taxation. However, if the spillover effects would be as significant as some suggest, this "novelty" would be short-lived as other countries adopt similar methods. Once this happens, Kenya and South Africa would be exactly in the same position as it is now-competing with other countries and regional blocks on the basis of non-taxrelated factors.

Moreover, if Kenya and South Africa were to adopt a destination-based VAT system adjusting for labor and while allowing for immediate loss refunds, they may end up in a worse position at that future point than they currently are. In such future 
situation, they would be constrained in taxing non-resident resource-exploiting companies; they would be dealing with a method that is volatile on account of investment cycles; the method would be heavily reliant on domestic sales; and they would be dealing with the increased risk of fraud arising from the immediate loss refund aspect.

Aside from the initial gains arising from being one of the first to implement a DBCFT system, it would not be feasible or wise for Kenya or South Africa to change to a DBCFT system.

\subsection{Conclusion}

Kenya and South Africa have adopted the arm's length principle in their respective domestic legislations as a mechanism to determine and allocate the profits of multinationals across different countries. While this is in keeping with international practice, it is not at all clear whether this is best suited for these two African developing countries.

In considering whether alternatives to the arm's length principle may be viable in the context of these two countries, this chapter has outlined the advantages and disadvantages to adopting either a unitary taxation system coupled with formulary apportionment or a DBCFT system-either in the form of a sales-only formulary apportionment or a destination-based VAT adjusted for wages.

While the implementation of a DBCFT (in either form) would not be suited for either Kenya or South Africa given the concern that its design would not effectively tax corporate profits and the prohibitive transitional costs involved in such a change, this chapter argues that a unitary taxation system with formulary apportionment holds promise. Unitary taxation would allow for the Kenyan and South African corporate income tax systems to more effectively reflect the economic realities of the many multinationals currently operating in these countries, would allow more efficiencies and fairness into the operation of the tax system, and would allow for government resources to be freed from transfer pricing issues to implementing unitary taxation. Moreover, the factors which make up the prevailing formula for formulary apportionment may be feasible in Kenya and South Africa given that they are both favorable destinations to host multinationals.

It has also been noted that should Kenya and South Africa succeed in agreeing on a formula, there is a strong likelihood that this may act as a catalyst for other African countries to reach consensus on the use of such a formula in their own jurisdictions-similar to what has occurred in the United States historically.

While it has often been noted that it is unlikely that global unitary taxation and formulary apportionment would take hold any time soon, such viewpoint in no way relieves countries from the necessity of making difficult decisions regarding which rules to follow in allocating income across jurisdictions. Amid the ever-growing calls for the fair allocation of income among countries, perhaps the time has come for African developing countries to take the path less travelled and to develop rules 
which would make the most economic sense for them. It is submitted that adopting a system of unitary taxation coupled with formulary apportionment may be a step in that direction.

\section{References}

\section{Treaties}

Agreement Establishing the African Continental Free Trade Area Agreement. (Signed 21 March 2018).

\section{Legislation}

Companies Regulations, 2011 (Government Gazette No. 34239) to the Companies Act, 71 of 2008 , regulation 30 read with regulation 28 (South Africa).

Income Tax Act, Chapter 470, section 18 (Kenya).

Income Tax Act, No. 58 of 1962, section 31 (South Africa).

\section{Articles}

Auerbach, A. J. (2010). A modern corporate tax. Washington, DC: Center for American Progress and Hamilton Project.

Auerbach, A. J. (2017). Demystifying the destination-based cash-flow tax. Brookings Papers on Economic Activity, 48(2), 409-432.

Auerbach, A. J., \& Devereux, M. P. (2013). Consumption and cash flow taxes in an international setting. NBER Working Paper No. 19579. National Bureau of Economic Research.

Auerbach, A. J., Devereux, M. P., \& Simpson, H. (2010). Taxing corporate income. In A. Stuart et al. (Eds.), Dimensions of tax design: The Mirrlees review (pp. 837-913). New York: Oxford University Press.

Auerbach, A., Devereux, M. P., Keen, M., \& Vella, J. (2017a). International tax planning under the destination-based cash flow tax. National Tax Journal, 70, 783-802.

Auerbach, A., Devereux, M. P., Keen, M., \& Vella, J. (2017b). Destination-based cash-flow taxation. Working Paper no. 17/01, Oxford University Centre for Business Taxation, pp. 1-92.

Avi-Yonah, R. S. (2007). The Rise and fall of arm's length: A study in the evolution of U.S. international taxation. Law \& Economics Working Papers Archive: 2003-2009. Retrieved September 6, 2019, from https://repository.law.umich.edu/law_econ_archive/art73

Avi-Yonah, R. S., \& Benshalom, I. (2011). Formulary apportionment: Myths and prospectsPromoting better international policy and utilizing the misunderstood and under-theorized formulary alternative. World Tax Journal, 3(3), 371-398.

Avi-Yonah, R. S., \& Clausing, K. (2017). Problems with destination-based corporate taxes and the Ryan blueprint. Columbia Journal of Tax Law, 8(2), 229-255.

Avi-Yonah, R. S., \& Musselli, A. (2019). Amazon Goldcrest project and the relevance of comparability analysis under the arm's length Principle. International Transfer Pricing Journal, 26(3), 159-166. 
Bird, R. M. (1986). The interjurisdictional allocation of income. Australian Tax Forum, 3(3), 333-353.

Bond, S., \& Devereux, M. P. (2002). Cash flow taxes in an open economy. C.E.P.R. Discussion Papers, No. 3401, Centre for Economic Policy Research.

Brooks, K. (2009). Tax sparing: A needed incentive for foreign investment in low-income countries or an unnecessary revenue sacrifice? Queen's Law Journal, 34(2), 505-564.

Carroll, M. B. (1934). Allocation of business income: The draft convention of the League of Nations. Columbia Law Review, 34(3), 473-498.

Cui, W. (2017). Destination-based cash-flow taxation: A critical appraisal. University of Toronto Law Journal, 67(3), 301-347.

De Graaf, A., De Haan, P., \& De Wilde, M. (2014). Fundamental change in countries' corporate tax framework needed to properly address BEPS. Intertax, 42(5), 306-316.

De Wilde, M. F. (2016). Taxation of multinational enterprises in a global market: Moving to corporate tax 2.0? Bulletin for International Taxation, 70(3), 182-187.

Donnelly, L. (2019, January 11). Giants cost SA billions in lost taxes. Mail and Guardian. Retrieved November 5, 2019, from https://mg.co.za/article/2019-01-11-00-giants-cost-sabillions-in-lost-taxes

Graetz, M. J. (2017). The known unknowns of the business tax reforms proposed in the house republican blueprint. Columbia Journal of Tax Law, 8(2), 117-170.

Green, R. A. (1993). The future of source-based taxation of the income of multinational enterprises. Cornell Law Review, 79(18), 18-86.

Grinberg, I. (2017). A destination-based cash flow taxation can be structured to comply with World Trade Organization rules. National Tax Journal, 70, 803-818.

Hamaekers, H. (1997). Can the free negotiation of prices within a multinational enterprise serve as an arm's length method? International Transfer Pricing Journal, 4(1), 2-4.

Hamaekers, H. (2001). Arm's length-How long? International Transfer Pricing Journal, 8(2), 30-40.

Hebous, S., Klemm, A., \& Stausholm, S. (2019). Revenue implications of destination-based cashflow taxation. International Monetary Fund. IMF Working Paper, No. 2019/7. https://doi.org/ $10.5089 / 9781484392935.001$

Hellerstein, W. (2005). Income allocation in the 21st century: The end of transfer pricing. International Transfer Pricing Journal, 12(3), 103-111.

Hertzig, N., Teschke, M., \& Joisten, C. (2010). Between extremes: Merging the advantages of separate accounting and unitary taxation. Intertax, 38(6/7), 334-349.

Kauder, L. M. (1993). Intercompany pricing and section 482: A proposal to shift from uncontrolled comparables to formulary apportionment now. Tax Notes, 58, 485-493.

Kelley, K. (2011, November 5). Kenya hosts 3 of Africa's top multinationals. The East African.

Kobetsky, M. (2008). The case for unitary taxation of international enterprises. Bulletin for International Taxation, 62(5), 201-215.

Langbein, S. I. (1986). The unitary method and the myth of arm's length. Tax Notes, 30, 625-683.

Okuth, E. (2018, November 18). KRA unearths tricks foreign firms use to dodge paying taxes. Daily Nation. Retrieved November 5, 2019, from https://www.nation.co.ke/news/How-foreignfirms-dodge-paying-taxes/1056-4856874-7brxkxz/index.html

Russo, R. (2005). Application of arm's length principle to intra-company dealings. International Transfer Pricing Journal, 12(1), 7-15.

Sadiq, K. (2001). Unitary taxation-The case for global formulary apportionment. Bulletin for International Taxation, 55(7), 275-286.

Sadiq, K. (2004). The fundamental failing of the traditional transfer pricing regime-Applying the arm's length standard to multinational banks based on a comparability analysis. Bulletin for International Taxation, 58(2), 67-81.

Shaviro, D. N. (2018). Goodbye to all that? A requiem for the destination-based cash flow tax. Bulletin for International Taxation, 72(4/5), 248-258. 
Turina, A. (2018). Back to grass roots: The arm's length standard, comparability and transparency-Some perspectives from the emerging world. World Tax Journal, 10(2), 295-348.

Waris, A. (2017). How Kenya has implemented and adjusted to the changes in international transfer pricing regulations: 1920-2016. ICTD Working Paper 69. Institute of Development Studies.

Weiner, J. M. (1999). Using the experience in the U.S. states to evaluate issues in implementing formula apportionment at the international level. OTA Paper 83, U.S. Department of the Treasury.

\section{Books and Chapters}

De Wilde, M. F. (2018). Chapter 2: The CCCTB relaunch: A critical assessment and some suggestions for modification. In P. Pistone (Ed.), European tax integration: Law, policy and politics (pp. 35-84). Amsterdam: IBFD.

Fargas Mas, L. M. (2018). Commentary on chapter 2: CCCTB relaunch: Why a destination-based model would not work. In P. Pistone (Ed.), European tax integration: Law, policy and politics (pp. 85-98). Amsterdam: IBFD.

McIntyre, M. J. (2003). The use of combined reporting by nation states. In B. J. Arnold, J. Sasseville, \& E. M. Zolt (Eds.), The taxation of business profits under tax treaties (pp. 245-298). Toronto: Canadian Tax Foundation.

McLure, C. E., \& Weiner, J. M. (2000). Deciding whether the European Union should adopt formulary apportionment of company income. In S. Cnossen (Ed.), Taxing capital income in the European Union: Issues and options for reform (pp. 243-292). New York: Oxford University Press.

Rogers-Glabush, J. (2015). IBFD international tax glossary (7th ed.). Amsterdam: IBFD.

\section{Organization Documentation}

Draft Convention Adopted for the Allocation of Business Income between States for the Purposes of Taxation, adopted by the Fiscal Committee at its last meeting, June 15th to 26th, 1933, and published as an annex to its report to the Council of the League. Document C.399.M.204.1933. II.A. F./Fiscal 76.

OECD. (2017). OECD transfer pricing guidelines for multinational enterprises and tax administrations 2017. Paris: OECD.

OECD. (2019). Mutual agreement procedure statistics. South Africa.

United Nations Economic Commission for Africa and the African Union Commission. (2014). Progress report on illicit financial flows: Why Africa needs to "track it, stop it and get it." UNECA.

United Nations Economic Commission for Africa and the African Union Commission. (2015). Report of the high level panel on illicit financial flows from Africa. UNECA. 


\section{Reports and Studies}

Deloitte. (2015). Transfer pricing in South Africa' presentation to the Portfolio Committee on Trade and Industry. Retrieved November 5, 2019, from https://www.thedti.gov.za/parliament/ 2015/Deloitte.pdf

Ernst \& Young. (2019). How can bold action become everyday action? EY attractiveness program Africa.

Global Financial Integrity. (2018). Kenya: Potential revenue losses associated with trade misinvoicing. GFI.

Independent Commission on the Reform of International Corporate Taxation. (2018). A roadmap to improve rules for taxing multinationals a fairer future for global taxation. ICRICT.

Initiative for Global Development and Dalberg Global Development Advisors. (2011). Pioneers on the frontier: Sub-Saharan Africa's multinational corporations. IGD and DGDA.

KPMG. (2015). Global transfer pricing review. Kenya: KPMG International Cooperative.

PricewaterhouseCoopers. (2012). Spotlight on Africa's transfer pricing landscape. Transfer Pricing Perspectives: Special Edition. PwC.

Readhead, A. (2016). Preventing tax base erosion in Africa: A regional study of transfer pricing challenges in the mining sector. Natural Resource Governance Institute.

Wier, L., \& Reynolds, H. (2018). Big and 'unprofitable': How 10\% of multinational firms do 98\% of profit-shifting. WIDER working paper 2018/111. United Nations University World Institute for Development Economics Research.

Open Access This chapter is licensed under the terms of the Creative Commons Attribution 4.0 International License (http://creativecommons.org/licenses/by/4.0/), which permits use, sharing, adaptation, distribution and reproduction in any medium or format, as long as you give appropriate credit to the original author(s) and the source, provide a link to the Creative Commons license and indicate if changes were made.

The images or other third party material in this chapter are included in the chapter's Creative Commons license, unless indicated otherwise in a credit line to the material. If material is not included in the chapter's Creative Commons license and your intended use is not permitted by statutory regulation or exceeds the permitted use, you will need to obtain permission directly from the copyright holder.

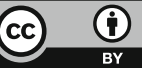

